\title{
Personality Competence Study Understanding the Expectations of Implementation 2013 Curriculum in Primary Schools
}

\begin{abstract}
Wachidi $^{*}$
Universitas Bengkulu, Indonesia

"Corresponding author.Email: wachidi@unib.ac.id

ABSTRACT

This study established the extent of comprehension of the competence of elementary school teachers in the implementation of the 2013 curriculum in Bengkulu. This research used methodological descriptive methods. This study clarified the extent of comprehension of the competence of elementary school teachers in the implementation of the curriculum for 2013. The study focused on 50 elementary school teachers in Bengkulu. This research contributed to the extent of understanding the personality competence of elementary school teachers in the implementation of the 2013 curriculum. The data collection was carried out using a questionnaire and a paper. The questionnaire was used to collect data on the extent of understanding the personality skill of teachers in primary school on 2013 curriculum. The expert was responsible for figuring out and confirming that the questionnaire was correct. The document was obtained and checked and processed using a percentage statistical system. The analysis of the data then concluded. The results obtained in detail that the level of comprehension of personality competence of teachers of Primary School in Bengkulu for 2013 curriculum is graded as very understanding.
\end{abstract}

Keywords: Personality competence, Implementing 2013 curriculum, Elementary school teacher.

\section{INTRODUCTION}

Teacher has a strategic role to play, especially in the forming character and building of student power. The presence of teachers is irreplaceable, particularly in our multicultural society, where the position of technology to replace the duty of teachers is still poor. Teacher has important model to evaluate the education. The teacher is the central focus of the classroom learning process. The revision of the curriculum must be accompanied by the professionalism of teachers. Skilled teachers are required to deliver high-quality graduates. Professionalism of teachers is a central factor in the adoption of the 2013 curriculum.

On the other hand, it was not as planned to take into account the educational credentials and history, so that it is said that teachers are not yet competent. This indicator is quantitatively described on the basis of the educational situation in Indonesia as follows: the low level of education due to various deciding factors, such as the variable of the curriculum, education medium, in adequate facility, parents and societies support, government support, learning strategy, students' interest and motivation, headmasters' management, the natural climate, the adverse social and cultural circumstances and the last teacher. Teacher is the master of learning process [1]; [2]; [3].
In another side there is a study which shows that teachers of SDN who teach properly was only $42.2 \%$, SDS who teach properly was 31.7 who teach suitably but improperly was $10.7 \%$, not suitable and improper was $9.0 \%$ from 283.715 teachers [4].

In providing maximum service for students, the key function of the teacher is to make students easier. to develop according to their potential. In addition, teachers are also required to be able to cultivate interest and motivation in learning so then each student has the will and ability to develop independently. In order to satisfy all student individuality, the instructor is also required to be able to establish a range of tools, media outlets and learning approaches, as well as try to make reforms in learning as professional demands. In addition, teachers also have a very strategic position, role and mission in enhancing the standard of learning. Teachers need to be trained to perform these tasks, responsibilities and duties equipped with academic qualifications and competencies in accordance with the standards set for educators.

The 2013 curriculum trial was conducted in 2013/2014 and appointed 6,221 schools in 295 districts/cities. The school consists of 2,598 SD, 1437 SMP, 1,165 SMA and 1,021 SMK. The Ministry of Education and Culture's decision to determine the number of pilot schools in all districts/cities is required to implement 2013 curriculum. Later on, the pilot 
schools mentioned above need to be evaluated. After being tested, 2013 curriculum is extended to different styles and levels of education. Doni Koesoema said efforts to repair and test the 2013 curriculum should ideally be for 1-2 years, accompanied by routine evaluations [14].

\section{Theoretical Basis}

The Ministry of National Education has approved the 2013 Curriculum for education either primary or secondary. The curriculum for 2013 is also referred to as 2013 curriculum. The program has been introduced in phases beginning in school year of 2014/2015. Entry into force of the curriculum for 2013 shows a transition from the Education Unit Level Curriculum to the 2013 curriculum. Curriculum reform is due to advances in science, technology, culture and arts, the new learning method, the changes also in centralized into decentralized management [6]. The 2013 curriculum is one of the learning components that plays a central role in the learning process in the classroom [5]; [6]; [7]. The curriculum for 2013 is planned, developed, implemented and evaluated to achieve educational goal. The curriculum for 2013 is used as a reference point for teachers in the application of the learning classroom process.

The curriculum for 2013 in various types and stages of education is primarily applicable to Law 20 of 2003 and Regulation 19 of 2005. The curricula for 2013 is the mandate of the Constitution 1945 to educate the country and ensure that the government seeks and implements a national education system regulated by law. [8]. Chapter1, paragraph 19 of Article 1 of the Law 20 of 2003 on the National Education System specifies that the curriculum is a set of plans and arrangements for the goals, content and learning materials, as well as the methods used to direct the implementation of learning activities in order to achieve certain educational objectives [9].

It is stated that the curriculum is defined as all the planned lessons learned under the supervision of the school and includes, of course, all school activities and planned school facilities, such as the library, health care, meetings, food service and lunch rooms, and field trips [10]. The curriculum is the experience of students who are planned to be led directly to the school, such as library services, health care, meetings, lunch rooms and field trips. Harian Nasional [11] says that: "Curriculum is written document which may contain many ingredients but basically it is a plan for the education of pupil during their enrolment in given school". [12] the curriculum is viewed as a learning plan, because what is learned about the learning process and the progress of an individual has an effect on the understanding of the curriculum.

\section{Basic competence}

\section{a. Definition of basic competence}

Irsyad [13] stated that competence is defined as the actual circumstances of the individual and the job. Meanwhile, from the Training Agency as stated by Kompas [14] that competence is a concept of something that a person working in a specific field of work should be able to do. It is a summary of the event, actions or result that an individual should be able to demonstrate. A common thread can be drawn that competence is a definition of what a person should be able to do in a job, in the form of actions, habits and outcomes that should be shown or demonstrated. In order for a person to be able to do something in his or her career, he or she must, of course, have the capacity in the form of expertise, attitude and skills in accordance with his or her field of work.

Majid [15] explains that the competencies possessed by each instructor will show the teaching quality of the teacher. This knowledge will manifest itself in the form of the mastery of information and of practitioners in the performance of their role as teachers. Maulana [16] suggests that competence is the intelligence that a person learns, perform a high order thinking.

Competence is defined as knowledge, skills and abilities controlled by someone who has become a part of himself in order to perform high order thinking. Majid [15] defines competence as the mastery of the task, the capacity, the attitude, and what is needed to facilitate development. Maslan [17] calls competence as the capacity of a person to do different job. Ristianti [18] stated competence is the underlying characteristic of an individual who is causally linked to the criterion referred to as good and/or superior performance in a job or situation. Competence is therefore a basic feature of an employee in relation to good performance criteria in a particular job and situation.

Furthermore, Spencer [26] it has been clarified that competence is said to be the underlying trait, because the traits are a deep and innate part of a person's personality and can predict various situations and styles of work. It has a causal relationship, since competence induces or predicts actions and results. It is called criterion-referred, since competence actually predicts who is performing well or poorly, on the basis of certain parameters or norms.

In line with the opinion of Ristianti [18], competence is generally defined as the adequacy of the mission or the possession of the requisite knowledge, skills and abilities. Competence is characterized as the possession of information and capabilities. Teachers must contribute to the process of learning. Law No 14 of 2005 describes pedagogical competence as the ability to monitor student learning. [19] calls this competence is the competence to handle learning. 


\section{b. Definition of Personality Competencies}

Personality competence meaning that the teacher must have a solid personality so that he can become a source of identification, especially for students, generally for fellow humans, meaning that he has an exemplary personality, so that he is able to carry out leadership "Ing Ngarso Sung Tulada, Ing Madya Mangun Karsa, Tut Wuri Handayani". The teacher as an executor of the task must be supported by a feeling of pride in the task entrusted to him to prepare the quality of the nation's future generation. Despite the heavy challenges and obstacles faced in carrying out their duties, teachers must remain strong in carrying out their duties as educators.

Education is a process that is planned so that all develop through the learning process. Teachers as educators must be able to control the process in accordance with principles that are deemed to be good and relevant in society.

Values, including norms, morals, aesthetics, and science, influence the ethical behavior of students as individuals and as members of society. A good application of discipline in the educational process will produce strong mental attitudes, character and personality of students. Teachers are expected to be able to teach their students self-discipline, learn to read, abide by rules/regulations, and learn how to act. All of that will be successful if the teacher is also disciplined in carrying out his duties and obligations. The teacher must have abilities related to the stability and integrity of a teacher's personality. The elements included include a) acting in accordance with Indonesia's religious, legal, social and national cultural norms; (b) presenting oneself as a truthful, noble character and role model for students and society; (c) presenting oneself as a person who is healthy, stable, mature, wise and dignified; (d) demonstrating work ethic, high responsibility, pride in being a teacher.

Another thing, according to [20] several indicators of teacher personality competence, among others, are as follows: (1) Teachers should love their position as teachers; (2) Teachers should be fair to their students; (3) Teachers should be patient and calm; (4) Teachers must be authoritative; (5) The teacher must be happy; (6) Teachers must be humane; (7) Teachers must cooperate with other teachers.

\section{Research Objectives and Benefits}

\section{a. General Purpose}

This study evaluated the level of awareness of the competencies of primary school teachers for the implementation of the curriculum in the Bengkulu Region in 2013 [36].

\section{b. Research Benefits}

1) Theoretical Benefits

Teacher competence is a construct of teacher behavior in 2013 curriculum developers or implementers in the field that is used by experts as a guide in understanding, explaining, assessing and even predicting this behavior. Based on the foregoing, the theoretical benefit in the goal of this study is to contribute to the theory of teacher competence, which is the cornerstone of the teaching foundation for the implementation of the 2013 curriculum [34]; [35].

\section{2) Practical Benefits}

The findings provide "feedback" to planners and policy makers or to school planning policies. The results of the research will be able to provide "feedback" to elementary school teachers in implementing 2013 curriculum in overcoming obstacles in implementing 2013 curriculum. The results of the research will be able to provide "feedback" to teachers, students, school principals, school inspectors, Kakanwil and the Government in this case the City and Provincial Education and Culture Ministry and the Central Ministry of Education and Culture in making policies related to 2013 curriculum. The results of the research will be able to provide "feedback" to the teacher to what extent the level of teacher competence on the implementation of 2013 curriculum. The results of the research will be able to provide "feedback" to the 2013 curriculum planners, implementers and developers, if there are deficiencies in planning, implementation and evaluation. The results of the research will be able to provide "feedback" to the Principal regarding the types of training needed to improve teacher competence. The results of the research will be able to provide "feedback" to policy makers in determining steps in receiving and implementing 2013 curriculum.

\section{RESEARCH METHODS}

This descriptive empirical research clarifies the extent of awareness of the pedagogical competence of elementary school teachers in Bengkulu City in the implementation of the 2013 curriculum. The site of this research is the Primary School in Bengkulu City. The subjects were 100 teaching teachers at Primary School in Bengkulu City. The goal of the study is related to the extent of knowledge of the professional competence of teachers in the implementation of the curriculum for 2013 [21].

Data collection methods are focused on questionnaires and records. The questionnaire was used to collect data on the extent of awareness of professional competence in the implementation of the 2013 curriculum. It was carried out with expert evaluation to see and prove that the questionnaire was correct [37]. 
The document is used to view data on teachers who teach at the Bengkulu City Primary School. After the data is obtained, the verification is carried out and then checked using percentage statistical techniques. After collection, it is analyzed and conclusions are drawn [22].

\section{RESULTS AND DISCUSSION}

\section{a. Research Results}

In detail, the results of this study indicate that: (a) Competence in acting in accordance with the religious norms adopted is $97.5 \%$ (very understanding); (b) Competence in implementing social values that apply in school by $90 \%$ (Very understanding); (c) Competence in implementing social values that apply in school at 98.5\% (Very understanding); (d) Competence in instilling moral values in students by $90.9 \%$ (very understanding); (e) Competence in instilling ethical values in students by $81.8 \%$ (Very understanding); (f) Competence in educating students to have a noble personality in school at $81.8 \%$ (Very understanding); (g) Competence in showing a stable, stable, mature, wise and authoritative personality of $81.8 \%$ (Very understanding); (h) Competence in being responsible for the tasks given by the Principal of $99.5 \%$ (Very understanding); (i) Competence in obeying the professional code of ethics for teachers, both at school and in the community is $90.9 \%$ (Very understanding).

Based on the data for each component of the personality competence, the level of understanding of the personality competence of teacher Primary School in Bengkulu City for the implementation 2013 curriculum shows an average of $80.21 \%$, which is considered to be very understanding.

The recommendations are: (a) Primary school teachers should act in accordance with the religious norms adopted; (b) Primary school teachers should carry out the social values that apply in school; (c) Elementary school teachers should instill moral values in students; (d) Elementary school teachers should instill moral values in students; (e) Elementary school teachers should educate students to have a noble personality; (f) Elementary school teachers should show a stable, stable, mature, wise and dignified personality; (g) Primary school teachers should be responsible for the tasks assigned by the Principal; (h) Primary school teachers should obey the professional code of ethics for teachers, both in school and in the community.

\section{b. Discussion of Research Results}

Based on [1] with the title: Implementation of Teacher Personality Competencies in Class IV A, Jageran Sewon Elementary School, Bantul [23], shows that the personality competencies that have been carried out by Class IV A teachers of Jageran Sewon
Elementary School include: devotion has not been reflected in daily activities Likewise, the noble morals of elementary school teachers have not yet been reflected. In contrast, elementary school teachers in Bengkulu City show high personality ownership compared to Jageran Sewon Bantul Public Elementary School teachers. There are similarities between primary school teachers in Bengkulu City and elementary school teachers in Bantul in that the two primary school teachers already have wisdom, wisdom, dignity, fairness and noble character [24];[25];[26].

Support from the research results of Agustin [3] with the title: The Effect of Teacher Personality Competence on Student Character Formation at Margorejo Public Elementary School, Surabaya, shows that the personality competency of Margorejo VI / 524 Public Elementary School teachers in Surabaya is 92.8\%, meaning the personality of elementary school teachers. is classified as a good personality. Therefore, there is an effect on integrity, religiosity, nationalist attitudes, independence of students, and mutual cooperation attitudes of students which are classified as good at $84.34 \%$ [27];[28];[29].

Another case with Darojah [7] in his research title: Analysis of the Effect of Teacher Personality Competence with Learning Motivation as an Intervening Variable on Student Achievement in Class $\mathrm{X}$ Office Administration shows that teacher personality competence has a positive and essential effect on student's learning motivation, so it can be concluded that the higher the teacher's personality competence, the higher the student's learning motivation. Support for the research results above was also carried out by [30]; [31]; [32] and [33] with the title of his research The Effect of Teacher Personality Competence on Student Success in Sociological Learning.

\section{CONCLUSION}

This study concluded that the extent of comprehension of the personality competence of Bengkulu City Elementary School teachers in the implementation of the 2013 curriculum is rated as very understanding.

\section{REFERENCES}

[1] Affifi, Z. E. (2016). Pelaksanaan Kompetensi Kepribadian Guru di Kelas IV A SD Negeri Jageran Sewon bantul. Yogyakarta: (t.p.), Skripsi.

[2] Anonim, (2003). Undang-Undang Sistem Pendidikan Nasional No. 20. Tahun 2003. Jakarta: (t.p).

[3] Agustin, I. T. (2019). Pengaruh Kompetensi Kepribadian Guru terhadap Pembentukan 
Karakter Siswa di SD Negeri Margorejo VI/524 Surabaya.Educational and Human Development Journal, Vol 5, N0 1 (2019) September 2019

[4] Beaucham, G. (1981). Curriculum Theory. Wilmette, Illinois: The Kagg Press.

[5] Chasbiansari, D. (2007). Kompetensi Sosial dan Kewirausahaan (Studi Korelasi pada Anggota Perkumpulan Wiarausahawan Mahasiswa Universitas Diponegoro Semarang) Skripsi: Semarang Universitas Diponegoro.

[6] Danim, S. (2003). Visi Baru Manajemen Sekolah. Jakarta: BumiAksara.

[7] Darojah, N. R., \& Hady, S. H. (2016). Analisis Pengaruh Kompetensi Kepribadian Guru dengan Motivasi Belajar sebagai Variabel Intervening terhadap Prestasi Belajar Siswa Kelas X Administrasi Pendidikan. Skripsi. (t.p). UPI.

[8] Depdiknas. (2005). Program Pengembangan Kurikulum Berbasis Kompetensi. Jakarta: Direktorat Pendidikan Lanjutan Pertama, Direktorat Jendral Pendidikan Dasar dan Menengah.

[9] Dewi, R. (2014). Pengaruh Kompetensi Profesional Guru terhadap Kreativitas Belajar IPA Siswa SD Se-Gugus Gajah Mada Paranggupito Wonogiri Tahun Ajaran 2014/2015.

[10] Depdiknas. (2006). Hasil Penelitian Balitbang Dikbud. Jakarta: Departemen Pendidikan Dasar dan Menengah.

[11] Harian Nasional. (2014). Kurikulum Diterapakan Bertahap. Jakarta: 14 Desember 2014.

[12] Hass, G. (1997). Curriculum Planning A New Approach. Boston: University of Florida.

[13] Irsyad, S. M. (2012). Pengaruh Kompetensi Profesional Guru dan Fasilitas Belajar Terhadap Hasil Belajar Siswa. (t.p).

[14] Kompas. (2014). Revisi Kurikulum 2013Butuh Waktu. Jakarta: 8 Desember 2014.

[15] Majid, A. (2005). Perencanaan Pembelajaran: Mengembangkan Standar Kompetensi Guru. Bandung: PT Remaja Rosda Karya.

[16] Maulana, R. (2014). Hubungan Komptensi Sosial dengan Kinerja Guru SD Islam Bunga Bangsa Samarinda Ditinjau dari Tipe Kepribadian. Skripsi. (tp.).

[17] Maslan. (2019). Hubungan Kompetensi Sosial Guru Kelas terhadap Penanaman Pendidikan Karakter.Singingi. Jurnal PAJAR (Pendidikan dan Pengajaran) Volume 3 Nomor 6 Nopember 2019.

[18] Ristianti, D. H., Danim, S., Winarto, H., \& Dharmayana, I. W. (2019). The Development Of Group Counselling Assessment Instruments. International Journal of Scientific \& Technology Research, 8(10).

[19] Ristianti, D. H., Putrajaya, G., \& Fathurrochman, I. (2020). Organizational behavior management through group counseling discussions as a radicalism preventive effort. Jurnal Konseling dan Pendidikan, 8(1), 23-31.

[20] Hasanah, M. L., \& Kristiawan, M. (2019). Supervisi Akademik dan Bagaimana Kinerja Guru. Tadbir: Jurnal Studi Manajemen Pendidikan, 3(2), 97-112.

[21] Fathurrochman, I. (2017). Implementasi Manajemen Kurikulum Dalam Upaya Meningkatkan Mutu Santri Pondok Pesantren Hidayatullah/Panti Asuhan Anak Soleh Curup. TADBIR: Jurnal Studi Manajemen Pendidikan, 1(1), 85-104.

[22] Muhnir. (2014). Analisis Kompetensi Sosial Guru Sekolah Dasar di Pulau Sapuka Kecamatan Liukang Tangaya Kabupaten Pangkep. Makassar. (Tp.) Skripsi.

[23] Mulyani, S. (1988). Kurikulum dan Pengajaran. Jakarta: Departemen Pendidikan dan Kebudayaan, Direktorat Jendral Pendidikan Tinggi, Proyek Pengembangan Lembaga Pendidikan Tenaga Kependidikan.

[24] Mulyasa. (2003). Mejadi Guru Profesional. Bandung: Remaja Rosda Karya.

[25] Nasution, S. (1988). Asas-asas Kurikulum. Bandung: Jemmars.

[26] Spencer, L. M., Jr \& Signe, M., Spencer. (1993). Competence at work: Models for Superior Perfromace. John Wiley \& Sons, Inc.

[27] Rafli, M. F. (2017). Pengaruh Kompetensi Sosial Guru terhadap Prestasi Belajar Mateamtika. Yogyakarta: (Tp.). Skripsi.

[28] Ratnawati, Y. (2013). Kompetensi Paedagogik Guru Sekolah Dasar Se-Kecamatan Kretek Kabupaten Bantul. Skripsi. (t.p).

[29] Ramayulis. (2013). Profesi dan Etika Keguruan. Jakarta: Kalam Mulia.

[30] Roestiyah, N.K. (1982). Masalah-masalah Ilmu Keguruan. Jakarta: Bina Aksara

[31] Stephen I., \& William B. M. (1982). Handbook in Research and Evaluation. Los Angeles California: University of Sourthen California.

[32] Robbin S. P. (2001). Perilaku Organisasi: Terjemahan oleh Benyamin Molan. Jakarta: PT Indeks.

[33] Sukmadinata, N. S. (1997). Pengembangan Kurikulum: Teori dan Praktik.Bandung: Rosda Karya.

[34] Umikalsum., \& Nsy, A. (2017). Implementasi Kompetensi Sspsial Guru Pendidikan Agama Islam di Sekolah Dasar Negeri 05 Pemulutan. Palembang. Skripsi. (Tp.)

[35] Undang - Undang Nomor 14 Tahun 2005 tentang Guru dan Dosen.

[36] Taba, H. (1962). Curriculum Development: Theory and Practice. New York: Harcout Brace and World, Inc.

[37] Yudha, A. (2017). Kompetensi Profesional Guru Sekolah Dasar. LINTERA Jurnal Ilmih Kependidikan, Vol 12. No. 1 (2017) 85 - 97) 